\title{
Response of body color change rearing under different light intensity conditions in farmed red spotted grouper, Epinephelus akaara
}

\author{
Song-Hee Choi ${ }^{1}$, Byeong-Hoon Kim ${ }^{1}$, Chi-Hoon Lee ${ }^{2}$ and Young-Don Lee ${ }^{1^{*}}$
}

\begin{abstract}
Background: Fish body color is one of the major factors that determine the commercial value of farmed fish, to understand for coloration mechanisms. The expression of melanin-related genes is according to the developmental stage and light intensity in the red spotted grouper, Epinephelus akaara.

Methods: To investigate changes in melanin formation and melanin-related genes in the larval development stage, fish larvae were reared from fertilized egg stage to 50 days after hatching (DAH). Experiment of body color changes was performed under each different light intensity conditions. Melanin-related genes expression was analyzed by real-time GPCR, and body coloration difference was represented by RGB (red, green, blue) code value.

Results: Expression levels of melanin-concentrating hormone (MCH) mRNA, pro-opiomelanocortin (POMC) mRNA, and melanocortin 1 receptor (MC1R) mRNA were at their highest 5 DAH (days after hatching). Expression levels of agoutisignaling protein (ASIP) mRNA were at their highest 10 DAH. Results of body color changes according to changes in light intensity conditions showed that the expression level of MCH mRNA in the 2000 Ix group was the highest at 6 weeks. The expression levels of POMC mRNA and MC1R mRNA in the 1000 lx group were at their lowest at 9 weeks. RGB color code value under different light intensities were the brightest under $1000 \mathrm{~lx}$ and the darkest under $0 \mathrm{~lx}$.

Conclusion: Our research suggests that POMC mRNA and MC1R mRNA in the red spotted grouper are involved in melanin synthesis, and these genes are thought to be controlled by light intensity. To better understand the molecular mechanism of coloration in the red spotted grouper, further studies are needed to clarify the relationship between melanophore development and melanin-related genes.
\end{abstract}

Keywords: Body coloration, Melanin-concentrating hormone (MCH), Pro-opiomelanocortin (POMC), Melanocortin 1 receptor (MC1R), Agouti-signaling protein (ASIP), Red spotted grouper

\section{Introduction}

Melanin is one of the major decision factors about hair and body color in vertebrate including human (Fujii 2000). It is synthesized in the melanosomes of melanocytes and affects skin and body color. Melanin cells receive external signals, such as from hormones and ultraviolet rays, that vitalize

\footnotetext{
* Correspondence: leemri@jejunu.ac.kr

${ }^{1}$ Marine Science Institute, Jeju National University, Jeju 695-965, Republic of Korea

Full list of author information is available at the end of the article
}

receptors. Oxidation of tyrosine is increased in melanosomes and the resulting tyrosinase induces melanin synthesis in the melanosomes (Seiji et al. 1963; Korner and Pawelek 1982; Kobayashi et al. 1994). Melanin transports through the dendrites of melanin cells to the skin's keratinocyte layer. Melanin protects skin tissues from cell deformation and destruction by UV rays (Sulaimon and Kitchell 2003; Costin and Hearing 2007; Kondo and Hearing 2011).

In marine animals, melanin has a protective function against ultraviolet rays, in that it protects cells against

(c) The Author(s). 2020 Open Access This article is licensed under a Creative Commons Attribution 4.0 International License, which permits use, sharing, adaptation, distribution and reproduction in any medium or format, as long as you give appropriate credit to the original author(s) and the source, provide a link to the Creative Commons licence, and indicate if changes were made. The images or other third party material in this article are included in the article's Creative Commons licence, unless indicated otherwise in a credit line to the material. If material is not included in the article's Creative Commons licence and your intended use is not permitted by statutory regulation or exceeds the permitted use, you will need to obtain permission directly from the copyright holder. To view a copy of this licence, visit http://creativecommons.org/licenses/by/4.0/ 
damage and stress (Adachi et al. 2005; Suzuki et al. 1994). The olive flounder (Paralichthys olivaceus) and octopus (Octopus vulgaris) have the ability to change skin color and camouflage themselves in response to predators and stress (Fujimoto et al. 1991; Fujii 1993; Hanlon 2007). Melanin in fish has numerous functions including, among others, skin protection, pigmentation, immunity, and stress responses (Amiya et al. 2008; Kittilsen et al. 2009; Sköld et al. 2013; Cal et al. 2017).

Pro-opiomelanocortin (POMC) is usually expressed in the pituitary gland and functions like many peptide precursors, including alpha-melanocyte-stimulating hormone $(\alpha-\mathrm{MSH})$, adrenocorticotropic hormone $(\mathrm{ACTH})$, and $\beta$ endorphin ( $\beta$-END). Melanocortin has five receptors from melanocortin 1 receptor (MC1R) to melanocortin 5 receptor (Cone 2006; Ducrest et al. 2008; Cerdá-Reverter et al. 2011; Ju et al. 2018). MC1R is involved in melanin synthesis and body color. MC2R is the receptor of $\mathrm{ACTH}$ and is involved in immune function. MC3R is involved in appetite and homeostasis. MC4R is involved in obesity and priapism, and MC5R is involved in immune regulation, separation of red blood cells, and the maintenance of homeostasis. $\alpha$-MSH stimulates the synthesis of melanin from melanocytes by revitalizing MC1R. This process darkens skin. The agouti-signaling protein (ASIP) prevents melanin pigmentation on the ventral side of fish by inhibiting $\alpha$-MSH synthesis which leads to the deactivation of MC1R (Cal et al. 2015). Melanin-concentrating hormone $(\mathrm{MCH})$, which is secreted by the brain, changes body color radically by controlling the cohesion and dispersion of melanin in the chromophore (Baker et al. 1995). It performs various other functions related to appetite and immunity (Takahashi et al. 2004; Matsuda 2009).

According to the Food and Agriculture Organization of the United Nations (FAO), the global production of grouper in aquaculture was 155,000 tons in 2015. The major producing countries are China, Taiwan Province of China (PoC), and Indonesia. These countries contribute $92 \%$ of the total production of grouper (Rimmer and Glamuzina 2019). Numerous grouper species studies have been performed on larval development stages as well as the growth and reproductive characteristics (Chauvet 1988; Song et al. 2005; Kim et al. 2013; Lee et al. 2014; Lee et al. 2020).

Serranidae have high industrial value in the domestic aquaculture industry, and some studies (growth (Cho et al. 2015), maturity (Lee et al. 2020), development (Song et al. 2005), digestive physiology (Hur et al. 2013), etc.) are being performed for the development of aquaculture technology. However, research on Serranidae was still rare.

The body color of farmed fish tends to decline in quality compared to wild fish (Booth et al. 2004). This is problematic because it reduces the commercial value of farmed fish. This problem also applies to many farmed grouper species, including the red spotted grouper Epinephelus akaara. Therefore, in order to improve the commercial value of farmed red spotted grouper, research on grouper coloration is required. The coloration of fish provides ecological and physiological information and is a decisive factor in their production value (Paripatananont et al. 1999; Kalinowski et al. 2005; Wang et al. 2006). In our study, we aimed to understand whether rearing red spotted grouper under different light intensity conditions affected their body color. In order to achieve this, we reared fish under different light intensity conditions and searched for the presence of melanin-related gene expression and changes in body color brightness.

\section{Materials and methods \\ Fish}

The fish, the artificially produced red spotted grouper was provided by the CR co. Itd (Republic of Korea) and moved to the Marine Science Institute, Jeju National University (Republic of Korea). Before the experiment, fish was acclimatized under natural photoperiod and water temperature conditions and fed to satiation the commercial pellets (Daebong lf fishery association Co., Jeju, South Korea) twice a day (09:00 and 17:00) for a week. All experiments were performed in compliance with the Animal Care and Use Committee guidelines of laboratory animals in the Republic of Korea (Borski and Hodson 2003).

\section{Experimental design}

For analysis of tissue specific expression of melanin-related genes, adult red spotted groupers $(n=3$, total length 245.3 $\pm 9.7 \mathrm{~cm}$, body weight $25.0 \pm 0.5 \mathrm{~g}$ ) were taken from the aquarium tank and anesthetized with $0.01 \%$ 2phenoxyethanol (Junsei Chemical Co., Tokyo, Japan) before sampling. After anesthetization, all tissues were extracted and divided into central nervous tissues (telencephalon, tectum, cerebellum, hypothalamus, medulla oblongata, and pituitary gland) and peripheral tissues (retina, tongue, heart, kidney, stomach, intestine, liver, gonad, fin, skin, and muscle). Extracted tissues were immediately frozen using liquid nitrogen and stored at $-80^{\circ} \mathrm{C}$ until analysis by realtime qPCR could be completed.

To investigate changes in melanin formation and melanin-related genes in the larval development stage, fertilized eggs were obtained from mature females and males. The fertilized eggs were transferred to individual tanks and allowed to hatch. Fish larvae were reared under natural photoperiod and natural water temperature conditions $\left(24.0 \pm 0.5^{\circ} \mathrm{C}\right)$. After hatching, fish larvae were sampled at $0,1,2,3,5,7,10,14,20,25,30,35,40,45$, and 50 days after hatching $(\mathrm{DAH})$. Samples were divided for genetic analysis and microscopic observations. Melanin distribution was observed using an optical microscope (BX43, Olympus Corporation, Tokyo, Japan). For real-time qPCR 
analysis, collected samples were immediately frozen in liquid nitrogen and stored at $-80^{\circ} \mathrm{C}$.

In order to investigate changes in melanin-related genes' expression according to light intensity, we performed a fish rearing experiment under different light conditions. Sixty DAH $(n=200$, total length $3.2 \pm 0.2 \mathrm{~cm}$, body weight $0.34 \pm 0.1 \mathrm{~g}$ ) larvae were reared. Fifty fish were randomly selected and divided from each aquarium tanks $(90 \mathrm{~L})$ and kept for 5 days under natural water temperatures and photoperiod conditions before the start of the experiment. Four light intensity conditions $(0 \mathrm{~lx}, 200 \mathrm{~lx}, 1000 \mathrm{~lx}$, and $2000 \mathrm{~lx}$ ) were regulated using a photometer, and light source used was LED lights. All experimental groups were reared under a $12 \mathrm{~h}$ light to $12 \mathrm{~h}$ dark (12 L:12D) photoperiod using a timer under natural water temperature conditions $\left(24.6 \pm 0.4{ }^{\circ} \mathrm{C}\right)$ for 9 weeks. The fish was fed commercial pellets (Daehan co., MP3, Busan, South Korea) twice a day during the experiment. Sampling was performed at 3-week intervals, a total of three times, on five fish from each tank. The fish was anesthetized using 0.01\% 2-phenoxyethanol, their weight was measured, and the entire length of skin and whole brain were extracted, including the pituitary gland. To analyze the body color difference between all experiments, the fish was photographed using a camera (F90X, Nikon, Tokyo, Japan). Following sampling, samples were immediately frozen in liquid nitrogen and stored at $-80^{\circ} \mathrm{C}$ until the real-time qPCR analyses could be performed.

\section{CDNA synthesis and real-time qPCR}

For total RNA extraction, a RiboEx ${ }^{\text {Tix }}$ (GeneAll Biotechnology, Seoul, Korea) solution was added to the brain, pituitary gland, and skin tissue samples and homogenized using a homogenizer. Total RNA was extracted according to the manufacturer's protocol and treated using diethyl pyrocarbonate-processed $\mathrm{H}_{2} \mathrm{O}\left(\right.$ DEPC $\mathrm{H}_{2} \mathrm{O}$ ) to cleanse and dissolve the total RNA pellet. Total RNA was measured using Nano Vue (GE Healthcare, Buckinghamshire, $\mathrm{UK}$ ) for cDNA synthesis. In the experiment, total RNA was synthesized using the RQ1 RNase-Free DNase Kit (Promega, Madison, WI, USA). The PrimeScript ${ }^{\mathrm{Tm}} 1$ st strand cDNA synthesis Kit (Takara Bio Inc., Otsu, Japan) was used for cDNA processing. To produce a speciesspecific primer for real time-qPCR, partially sequenced melanin-related genes were used (Table 1). Real-time qPCR was performed with $0.2 \mu \mathrm{L}$ of cDNA using an Evagreen premix PCR kit (ABM, Richmond, BC, Canada). Real time-qPCR was performed with an initial denaturation at $95^{\circ} \mathrm{C}$ for $10 \mathrm{~min}$ after a reaction at $95^{\circ} \mathrm{C}$ for $15 \mathrm{~s}$ and $60^{\circ} \mathrm{C}$ for $1 \mathrm{~min}$ using a CFX96 $6^{\text {ma }}$ real-time system (Bio-Rad Laboratories, Hercules, CA, USA). Expression of genes in each experiment was normalized to amount of the internal control $\beta$-actin gene.
Table 1 Primer sets used in real time-quantitative PCR

\begin{tabular}{ll}
\hline Primer information & \\
\hline Primer & Sequence (5'-3') \\
MCH Forward & CTGTTGTCGTCAGCTCTCCG \\
MCH Reverse & GGGATGCAGATCTACCCACTG \\
POMC Forward & GAACATCCGAGCTGTCAGGA \\
POMC Reverse & CATGGAGTAGGAGCGCTTGG \\
MC1R Forward & GTTGGCCATCTTCAAGAACCG \\
MC1R Reverse & TCACGTCGATGACGTTTCC \\
ASIP Forward & GGCCCACCTCCTGTTGTATT \\
ASIP Reverse & GACAGTTCTGAAGAGCCGACA \\
$\beta$-actin Forward & GAGGGGTATCCTGACCCTGA \\
$\beta$-actin Reverse & CTCCTCAGGGGCAACTCTC \\
\hline
\end{tabular}

\section{RGB color code}

The RGB color code for the body color change in fish by light intensity was analyzed by obtaining the average color of an image. A color code was extracted from each image (of equal area) using a free online program Get average color of image by Matthias Klein (Klein 2018).

\section{Statistical analysis}

The experimental results were analyzed with a one-way analysis of variance (ANOVA) using SPSS version 21 (SPSS Inc.) and tested using Duncan's multiple range test (Duncan 1955) to confirm significance. Values are shown as means \pm standard deviations. Statistical significance was determined at a $95 \%$ level $(P<0.05)$.

\section{Results}

Tissue-specific expression of melanin-related genes

We aimed to detect expression of $\mathrm{MCH}, \mathrm{POMC}, \mathrm{MC1R}$, and ASIP mRNAs in the red spotted grouper's central nervous and peripheral tissues. MCH mRNA expression was significantly higher than the other tissues in the diencephalon $(P<0.05)$ (Fig. 1a). POMC mRNA expression was significantly higher than the other tissues in the pituitary gland $(P<0.05)$ (Fig. 1b). MC1R mRNA showed significantly high expression, especially in pelvic fin tissues $(P<0.05)$ (Fig. 1c). The expression of ASIP mRNA was significantly higher in the tongue and ventral skin $(P<0.05)$ (Fig. 1d).

\section{Developmental stages: melanin formation and melanin- related genes changes}

We investigated melanophore formation changes according to development stage in red spotted grouper larvae. At $0 \mathrm{DAH}$, melanophores were not observed (Fig. 2a). At 1 DAH, a melanin line was observed outside each retina (Fig. 2b). At $2 \mathrm{DAH}$, melanin had begun to spread from the melanin line outside each retina (Fig. 2c). At $3 \mathrm{DAH}$, the whole retina of each larva was covered by melanophores and more melanophores had begun to develop at 

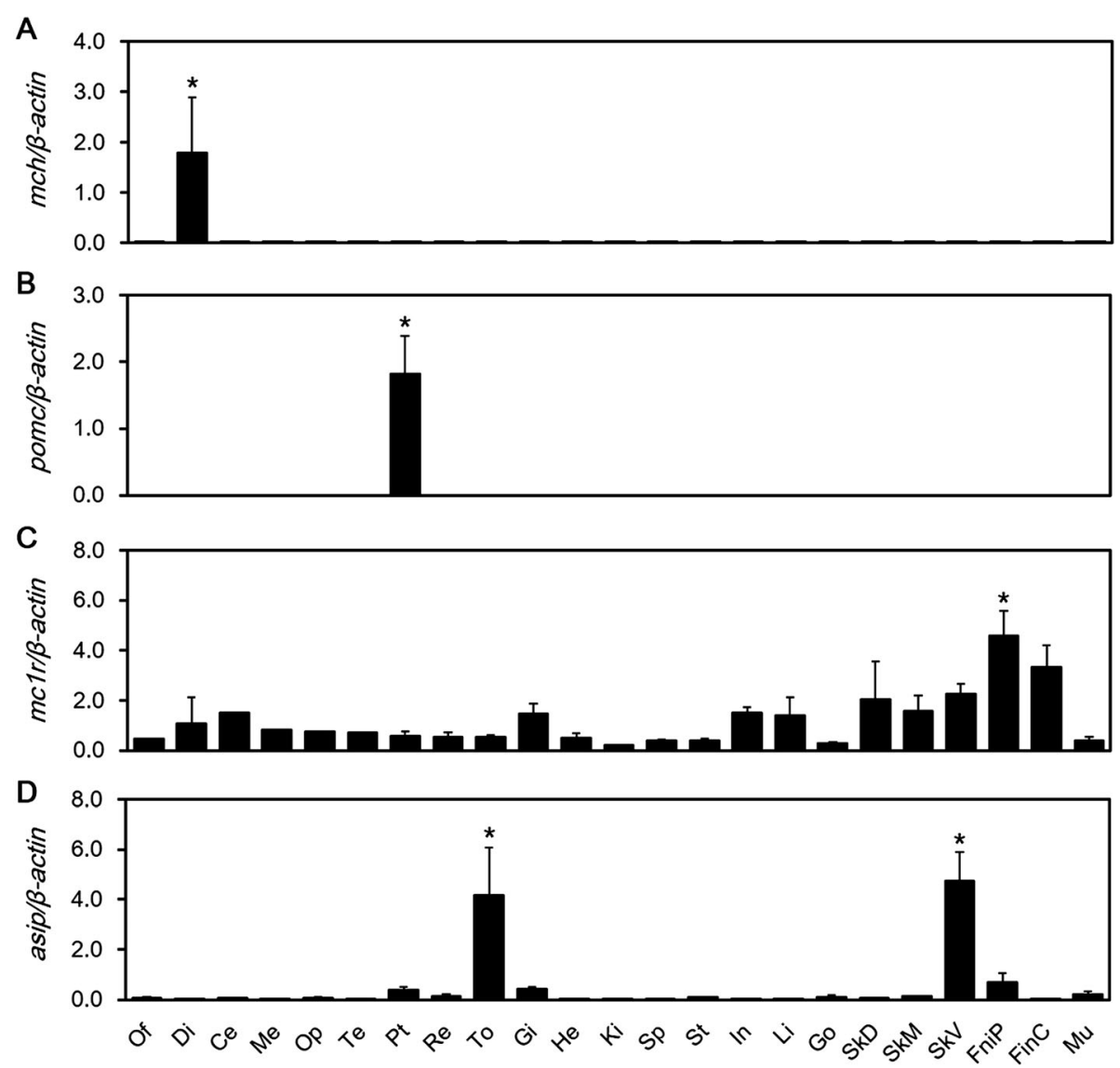

Fig. 1 Tissue specific expression of melanin-related genes in the red spotted grouper by real-time qPCR. Of, olfactory lob; Te, telencephalon; Op, optic tectum; Di, diencephalon; Ce, cerebellum; Me, medulla oblongata; Pt, pituitary; Re, retina; To, tongue; Gi, gill; He, heart; Ki, kidney; Sp, spleen; St, stomach; In, intestine; Li, liver; Go, gonad; SkD, skin dorsal; SkM, skin middle; SkV, skin ventral; FinP, pelvic fin; FinC, caudal fin; Mu, muscle. Asterisks represent highest statistical difference at $P<0.05$. Values are mean $\pm \mathrm{SEM}$

the primordial fin fold and abdominal cavity of each larva (Fig. 2d). At 5 DAH, melanophores in the abdominal cavity were spread out to the vertebra of each larva (Fig. 2e). At $10 \mathrm{DAH}$, the distribution range of the vertebral melanophores had widened in each larva (Fig. 2f). At 14 DAH, the abdominal cavity of each larva was completely covered by melanophores (Fig. 2g). At 20 DAH, melanophores were observed in the caudal fin of each larva (Fig. 2h). At $25 \mathrm{DAH}$, melanophores were distributed at the edges of the dorsal fins, and an increase in melanophores was observed at the caudal fins in each larva (Fig. 2i). At 30 DAH, melanophores from the caudal fin began to develop round to the center and sides of each body (Fig. 2j). At 40 DAH melanophores had developed at the dorsal fin and at the edge of dorsal and lateral lines of each larva (Fig. 2k). At $50 \mathrm{DAH}$, melanophores were observed at the dorsal fin and over the whole body (Fig. 2l).

Expression changes of $\mathrm{MCH}, \mathrm{POMC}, \mathrm{MC} 1 \mathrm{R}$, and ASIP mRNAs according to development stage were observed in red spotted grouper. MCH mRNA expression increased at $3 \mathrm{DAH}$, was at its significantly high levels at 5 DAH $(P<0.05)$, then decreased radically thereafter (Fig. 3a). Expression of POMC mRNA increased at $3 \mathrm{DAH}$, was at its significantly high levels at 5 DAH $(P<0.05)$, and then decreased until 14 DAH where it remained at low levels of expression (Fig. 3b). Expression of MC1R mRNA was significantly high until 5 DAH $(P<0.05)$, then it decreased until $25 \mathrm{DAH}$ where it remained at low levels thereafter (Fig. 3c). The expression of ASIP mRNA started by increasing slowly until $10 \mathrm{DAH}$ and significantly high levels at $10 \mathrm{DAH}$ and $20 \mathrm{DAH}(P<0.05)$. Then, it decreased steadily until 50 DAH (Fig. 3d).

\section{Changes in melanin-related genes expression according to light intensity}

At 6 weeks, the expression of MCH mRNA was at its highest level at $2000 \mathrm{~lx}$ and its lowest level at $0 \mathrm{~lx}(P<$ $0.05)$. However, at 9 weeks, there was no significant difference between the experimental groups (Fig. 4a). At 6 weeks, the expression of POMC mRNA was highest at $200 \mathrm{~lx}$, and at 9 weeks, the highest level was confirmed 


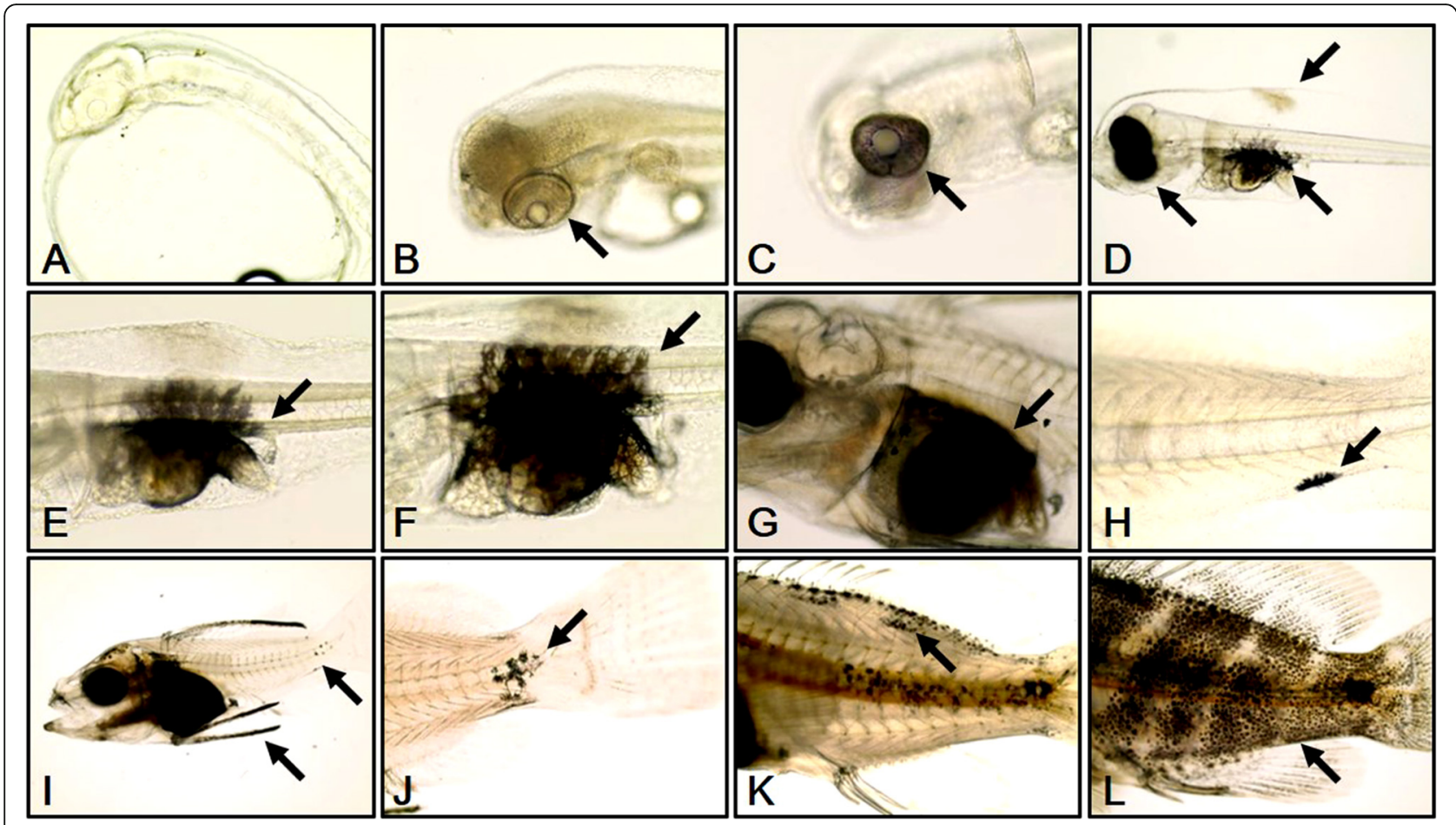

Fig. 2 Development stage of pigmentation in the red spotted grouper. 0 DAH (a), 1 DAH (b), 2 DAH (c), 3 DAH (d), 5 DAH (e), 10 DAH (f), 14 $\mathrm{DAH}(\mathbf{g}), 20 \mathrm{DAH}(\mathbf{h}), 25 \mathrm{DAH}(\mathbf{i}), 30 \mathrm{DAH}(\mathbf{j}), 40 \mathrm{DAH}(\mathbf{k}), 50 \mathrm{DAH}(\mathbf{I}) . \mathrm{DAH}$, days after hatching; arrows indicate melanin

at $0 \mathrm{~lx}$. The lowest level of POMC mRNA was confirmed at $1000 \mathrm{~lx}(P<0.05)$ (Fig. 4b). Expression of MC1R mRNA was at its highest level at $200 \mathrm{~lx}$, and at 3 weeks, it was at its lowest at $2000 \mathrm{~lx}(P<0.05)$. However, at 6 weeks, there was no significant difference in the expression of MC1R mRNA between the experimental groups. At 9 weeks, the highest level was observed at $0 \mathrm{~lx}$, and the lowest level was observed at $1000 \mathrm{~lx}$ (Fig. 4c). The expression of ASIP mRNA was at its highest level immediately after the beginning of the experiment. It then maintained a low level of expression and showed no significant difference between the experimental groups (Fig $4 d)$. When we measured the RGB color value of the red spotted grouper's skin, the 0 lx group returned values of 86,71 , and 58 as their darkest colors. The RGB values from the $200 \mathrm{~lx}$ group were 88, 71, and 59 and from the $1000 \mathrm{~lx}$ group were 137, 116, and 99, in which $1000 \mathrm{~lx}$ was the brightest colors. The RGB values of the $2000 \mathrm{~lx}$ group were 105, 92, and 81 (Table 2).

\section{Discussion}

Recently, photobiology studies on fish have been conducted on various adaptive physiological characteristics, including body color, growth, and metabolism (Appelbaum and Kamler 2000; Petrell and Ang 2001). This study investigated the adaptive physiology of red spotted grouper's melaninrelated genes with respect to light intensity. According to our results, the expression of genes related to melanin development in red spotted grouper larvae showed that the expression of $\mathrm{MCH}, \mathrm{POMC}$, and MC1R mRNAs began to increase at $3 \mathrm{DAH}$, with the highest levels observed at 5 DAH. During this period, melanophores completely covered the body and started to form dorsal fin fold and abdominal cavities. These results are considered to reflect the activation of melanin-related genes' expression from 3 $\mathrm{DAH}$ to $5 \mathrm{DAH}$, which leads to melanin synthesis in the red spotted grouper. ASIP mRNA was highly expressed 7 to $25 \mathrm{DAH}$, and during this period, the abdominal cavity was covered with melanophores and the outer part of the abdominal cavity was surrounded by iridophores.

The ASIP gene prevents the division and increase of melanin cells and makes skin color brighter (Suzuki 2013). From experimental results on goldfish (Carassius auratus) (Cerdá-Reverter et al. 2005), ASIP mRNA was found to have a genetic homogeny of mammal ASIP mRNA, along with mice, and it plays an important role in forming the ventral color pattern. In goldfish, ASIP mRNA is mainly expressed in ventral skin and has not been detected in dorsal skin. These results suggest that ASIP mRNA is mainly involved in differentiation to iridophores in ventral skin. Therefore, the increased ASIP mRNA expression in red spotted grouper larvae at 7 DAH, that we observed, may stimulate the development of iridophores outside the abdominal cavity.

Melanophores in red spotted grouper larvae specimens were observed at $1 \mathrm{DAH}$ formed outside the iris and 


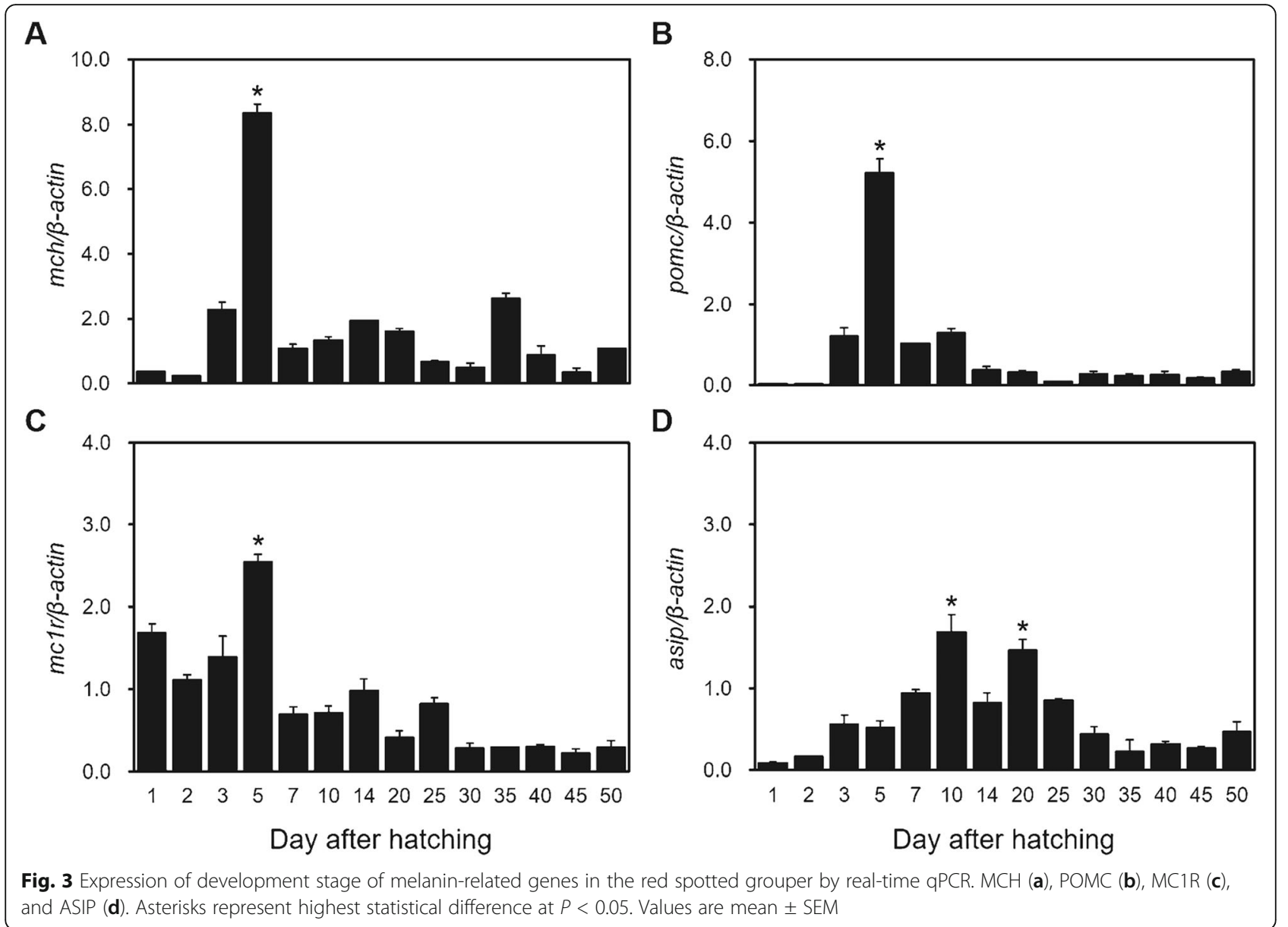

shaped in a ring. At $3 \mathrm{DAH}$, the melanophore was observed, in each specimen, in the dorsal fin fold and abdominal cavity. At $5 \mathrm{DAH}$, the melanophore was observed at the lateral line in larvae. At $20 \mathrm{DAH}$, larvae coloration started to develop when the expression of the melanophore was at the end of lateral line. At $40 \mathrm{DAH}$, the melanophore started to color the whole body and tail fin. The body color development of red spotted grouper larvae showed a similar development pattern as the brown-marble grouper (Epinephelus fuscoguttatus), which is in the same family (Kohno et al. 1993). The color development of brownmarble grouper larvae also starts with observation of melanophores in the eyes, after which it develops chromophores throughout the abdominal cavity, dorsal fin spine, and caudal parts. The melanophore starts to condense at the dorsal fin spine and caudal parts, and the body color develops through the head, tail, dorsal fin spine, and whole body. However, some studies have reported melanophore development stages that differ from our results. In rock porgy (Oplegnathus punctatus), the melanophore can be observed before hatching (Park et al. 2015). The rock porgy's melanophore pigments move back to the head and surround the myotome throughout the tail at fertilization after $15 \mathrm{~h}$, which is termed organogenesis. When hatched, the melanophore is already developed around the oil drop and covers the body's entire skin surface. In starry flounder (Platichthys stellatus), before larval melanophore development in the eyes, the melanophore has already begun to develop in the primordial fin and tail (Yamashita et al. 2014). After melanophore development has been completed in the eyes, the melanophore begins to develop throughout the body from the primordial fin fold and body center. Based on these contrasting results, melanophore development patterns are likely to be species-specific.

We investigated melanin-related gene expression in red spotted grouper according to different light intensities. At 6 weeks, MCH mRNA tended to increase its expression levels with an increase in light intensity. However, the expressions of POMC mRNA and MC1R mRNA were highest at $0 \mathrm{~lx}$ and lowest at $1000 \mathrm{~lx}$. At the end of the experiment, the expression of MC1R mRNA was at its highest at $0 \mathrm{~lx}$ and its lowest at $1000 \mathrm{~lx}$. In case of MC1R mRNA expression, it was significantly higher in dark conditions in the 3 weeks and 9 weeks, and there was no significant difference in the 6 weeks, but in the dark conditions, MC1R mRNA expression tended to be high. 

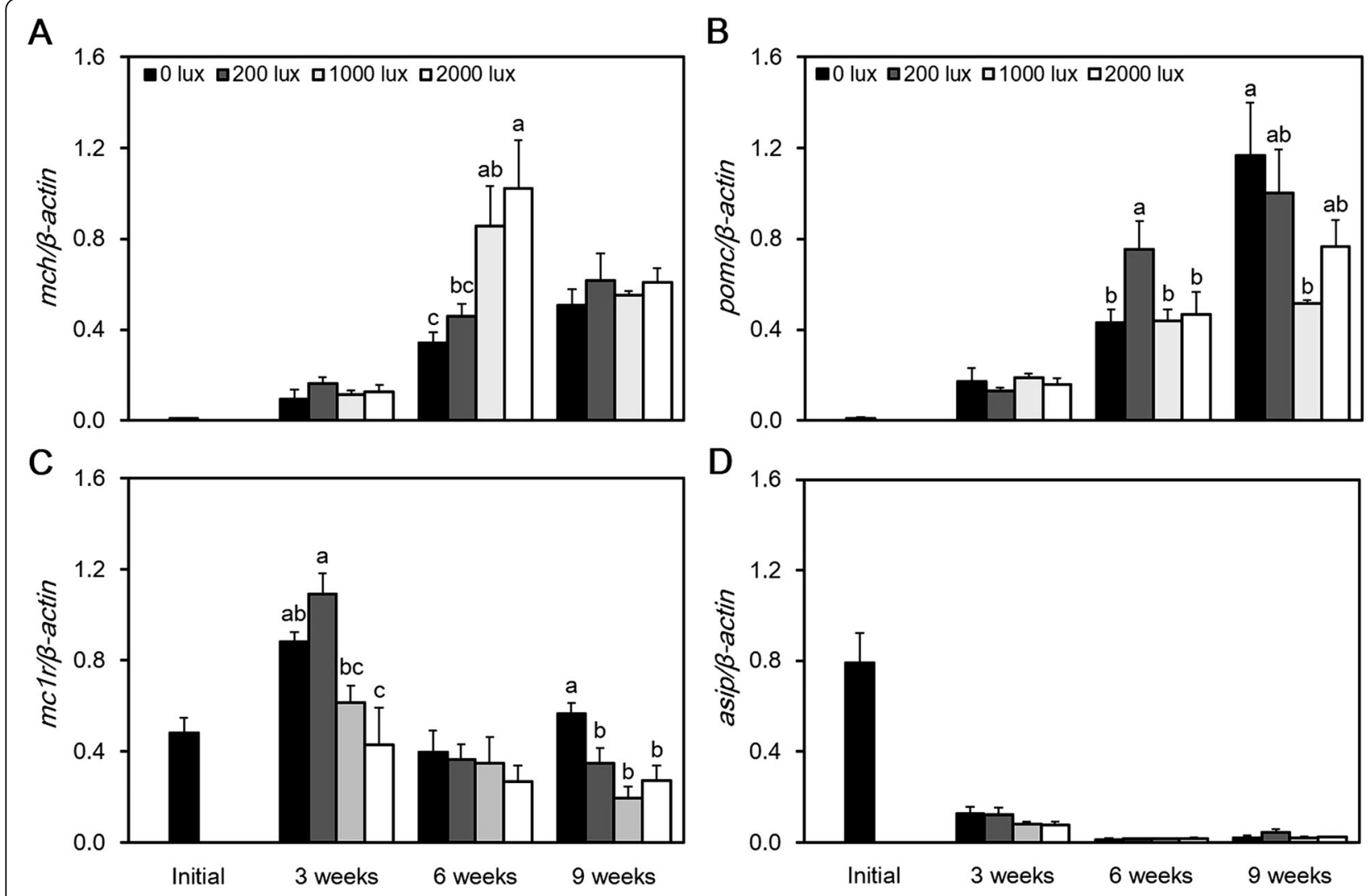

Fig. 4 Expression changes of melanin-related genes in the red spotted grouper brain, pituitary, and skin under different light intensity conditions by real-time qPCR. MCH (a), POMC (b), MC1R (c), and ASIP (d). The different letters indicate statistical difference at $P<0.05$. Values are mean \pm SEM

However, the expression of ASIP mRNA was at its highest during the initial period of the experiment but maintained a low level of expression afterwards. In terms of body color (RGB cord value), the darkest color value was observed in the $0 \mathrm{~lx}$ group, and bright color value was observed in the $200 \mathrm{~lx}, 2000 \mathrm{~lx}$, and the $1000 \mathrm{~lx}$ groups.

A lot of research studies have reported that $\mathrm{MCH}$ is closely involved with background color (Yamanome et al. 2005; Chung et al. 2018; Diniz and Bittencourt 2019; Kasagi et al. 2020). To observe morphological color changes in goldfish, fish was reared under different background color conditions and the expression of M1CR, MC5R, MSH, $\mathrm{MCH}$, and ASIP mRNAs was checked (Mizusawa et al. 2018). In the white-reared fish, MCH mRNA expression was higher than that in black-reared fish, and POMC mRNA expression was lower than that in the black-reared fish. In the xanthophores in the scale, MC1R did not always follow the background color change, but MC5R followed

Table 2 RGB code value extracted form red spotted grouper skin. 0 lux (A) 200 lux (B) 1000 lux (C) and 2000 lux (D)

\begin{tabular}{lllll}
\hline & 0 lux & 200 lux & 1000 lux & 2000 lux \\
\hline RGB (Red, Greed, Blue) & $86,71,58$ & $88,71,59$ & $137,116,99$ & $105,92,81$ \\
\hline
\end{tabular}

the background color change. Mizusawa was suggested that MC5R might be a major factor reinforcing the function of MSH in morphological color change. ASIP mRNA has high expression in the ventral skin but no expression in the dorsal skin. Therefore, MC1R, MC5R, MCH, and MSH were associated with background color adaptation and ASIP mRNA might be not.

Many studies have aimed to determine the effects of light intensity on survival rate, growth, swimming, feeding, coloration, and various other physiological phenomena (Batty et al. 1990; Boeuf and Le Bail 1999; Reichard et al. 2002; Richmond et al. 2004; Luchiari et al. 2006; Liu et al. 2012; Lee et al. 2017). Light can induce melanogenesis and increase the synthesis of the melanophore, which can make the body coloration darker (Odiorne 1957). When the Australian snapper (Pagrus auratus) was reared under different degree of shading conditions ( $0 \%, 50 \%$, and $95 \%$ shading form incident radiation), the group under the $0 \%$ degree of shading conditions showed darker body coloration than the other groups (Booth et al. 2004). In addition, the body color of Chinese longsnout catfish (Leiocassis longirostris) tends to be dark under a strong light intensity, and their survival rate tends to drop under extremely strong light intensity conditions (Han et al. 
2005). This study indicates that the light intensity affects melanin synthesis. In these experiments, we conclude that the light sources such as sun or ultraviolet rays stimulate the skin and lead to melanin synthesis for skin protection. And by that result, the body colors became more dark.

Research on body color change in red porgy (Pagrus pagrus) as a result of changes in light intensity has shown that red porgy tends to have bright body coloration beside a white background with a high intensity of light (Pavlidis et al. 2008). After observing body color change in ocellaris clownfish (Amphiprion ocellaris) under 20-50, 600-850, and 2700-3500 lx conditions, specimens were found to have a bright color on their back and tail fins under low intensity light (Yasir and Qin 2009). These results indicate that the body color has adapted to the environment condition, affected by the amount of light. These researches suggest that light intensity can affect body color. Comparing our research results, the bright light intensity is thought to brighten up the body color because of the melanin concentrated due to increased expression of $\mathrm{MCH}$ mRNA, and melanin synthesis decreased due to reduced expression of POMC and MC1R mRNA.

In our study on the melanin-related genes of the red spotted grouper, POMC mRNA, MC1R mRNA, and MCH mRNA showed different gene expression patterns under different light intensity conditions. The expression of ASIP mRNA was not affected by light intensity. It is thought that under controlled light intensity conditions, the expression of POMC mRNA and MC1R mRNA induces melanin synthesis. The concentration of $\mathrm{MCH}$ mRNA was affected by light conditions. The low expression of ASIP mRNA is most likely due to the development of iridophores in the abdominal cavity as the larvae grew.

\section{Conclusion}

The aim of this study is the change in the body color and melanin-related gene expression of red spotted grouper by light intensity. Our results suggested that when light intensity goes stronger, $\mathrm{MCH}$ mRNA expressed higher, and POMC and MC1R mRNAs expressed lower. However, ASIP mRNA expression did not changed. With these results, we suggest that $\mathrm{MCH}, \mathrm{POMC}$, and MC1R mRNAs are affected by light intensity. Further research is needed to understand the relationship between melanin composition and gene expression in relation to the external environment and body color change. Our study contributes valuable baseline data that advances our knowledge of body color stimulation under environmental conditions in the red spotted grouper.

\section{Abbreviations}

POMC: Pro-opiomelanocortin; MC1R: Melanocortin 1 receptor; ASIP: Agoutisignaling protein; $\mathrm{MCH}$ : Melanin-concentrating hormone

\section{Acknowledgements}

This work was supported by the Korea Institute of Planning and Evaluation for Technology in Food, Agriculture, Forestry (IPET) through Golden Seed Project, funded by Ministry of Oceans and Fisheries (MOF) (grant number 213008-05-4-SB510).

\section{Authors' contributions}

$\mathrm{SH}$ designed and carried out the data analysis and manuscript writing. $\mathrm{BH}$ and $\mathrm{CH}$ participated in the fish sampling and data analysis. YD participated in its design and coordination and helped to draft the manuscript. All authors read and approved the final manuscript.

\section{Funding}

This work was supported by the Korea Institute of Planning and Evaluation for Technology in Food, Agriculture, Forestry (IPET) through Golden Seed Project, funded by Ministry of Oceans and Fisheries (MOF) (grant number 213008-05-4-SB510).

\section{Availability of data and materials Not applicable.}

Ethics approval and consent to participate

All experiments were conducted in compliance with both the Animal Care and Use Committee guidelines of the Jeju National University.

\section{Consent for publication}

Not applicable.

\section{Competing interests}

The authors declare that they have no competing interests.

\section{Author details}

Marine Science Institute, Jeju National University, Jeju 695-965, Republic of Korea. ${ }^{2}$ CR Co., Ltd, Jeju 63333, South Korea.

Received: 23 March 2020 Accepted: 27 October 2020

Published online: 03 December 2020

\section{References}

Adachi K, Kato K, Wakamatsu K, Ito S, Ishimaru K, Hirata T, Osamu M, Kumai H. The histological analysis, colorimetric evaluation, and chemical quantification of melanin content in 'suntanned'fish. Pigment Cell Res. 2005;18:465-8.

Amiya N, Amano M, ligo M, Yamanome T, Takahashi A, Yamamori K. Interaction of orexin/hypocretin-like immunoreactive neurons with melaninconcentrating hormone and a-melanocyte-stimulating hormone neurons in brain of a pleuronectiform fish, barfin flounder. Fisheries Sci. 2008;74:1040-6.

Appelbaum S, Kamler E. Survival, growth, metabolism and behaviour of Clarias gariepinus (Burchell 1822) early stages under different light conditions. Aquacult Eng. 2000;22:269-87.

Baker B, Levy A, Hall L, Lightman S. Cloning and expression of melaninconcentrating hormone genes in the rainbow trout brain. Neuroendocrinology. 1995;61:67-76.

Batty RS, Blaxter JHS, Richard JM. Light intensity and the feeding behavior of herring, Clupea harengus. Mar Biol. 1990;107:383-8.

Boeuf G, Le Bail PY. Does light have an influence on fish growth? Aquaculture. 1999:177:129-52.

Booth MA, Warner-Smith RJ, Allan GL, Glencross BD. Effects of dietary astaxanthin source and light manipulation on the skin colour of Australian snapper Pagrus auratus (Bloch \& Schneider, 1801). Aquac Res. 2004;35:458-64.

Borski RJ, Hodson RG. Fish research and the institutional animal care and use committee. Ilar J. 2003;44:286-94.

Cal L, Gómez-Marín C, Gómez-Skarmeta JL, Cerdá-Reverter JM, Kelsh RN, Rotllant J. A Bac transgenic analysis of the asip1 locus reveals developmental mechanisms of dorso-ventral pigmentation in fish. In: The International Symposium on Genetics in Aquaculture XII. James HT, Shawn DC and Leigh AB, eds. Santiago de Compostela, Spain. 2015; 122.

Cal L, Suarez-Bregua P, Cerdá-Reverter JM, Braasch I, Rotllant J. Fish pigmentation and the melanocortin system. Comp Biochem Phys A. 2017;211:26-33.

Cerdá-Reverter JM, Agulleiro MJ, Guillot R, Sánchez E, Ceinos R, Rotllant J. Fish melanocortin system. Eur J Pharmacol. 2011;660:53-60. 
Cerdá-Reverter JM, Haitina T, Schiöth HB, Peter RE. Gene structure of the goldfish agouti-signaling protein: a putative role in the dorsal-ventral pigment pattern of fish. Endocrinology. 2005;146:1597-610.

Chauvet C. Etude de la croissance du mérou Epinephelus guaza (Linné, 1758) des côtes tunisiennes. Aquat Living Resour. 1988;1:277-88.

Cho HC, Kim JE, Kim HB, Baek HJ. Effects of water temperature change on the hematological responses and plasma cortisol levels in growing of red spotted grouper, Epinephelus akaara. Dev Reprod. 2015;19:19-24.

Chung IY, Jeon JM, Song YH. Characterization of melanin-concentrating hormone from olive flounder (Paralichthys olivaceus). J. Life Sci. 2018;28:284-92.

Cone RD. Studies on the physiological functions of the melanocortin system. Endocr Rev. 2006;27:736-49.

Costin GE, Hearing VJ. Human skin pigmentation: melanocytes modulate skin color in response to stress. Faseb J. 2007:21:976-94.

Diniz GB, Bittencourt JC. The melanin-concentrating hormone $(\mathrm{MCH})$ system: a tale of two peptides. Front Neurosci-Switz. 2019;13:1280.

Ducrest AL, Keller L, Roulin A. Pleiotropy in the melanocortin system, coloration and behavioural syndromes. Trends Ecol Evol. 2008;23:502-10.

Duncan DB. Multiple range and multiple F tests. Biometrics. 1955;11:1-42.

Fujii R. Coloration and chromatophores. In: Evans DH, editor. The physiology of fishes. Boca Raton: CRC Press; 1993. p. 535-62.

Fujii R. The regulation of motile activity in fish chromatophores. Pigm Cell Res. 2000;13:300-19.

Fujimoto M, Arimoto T, Morishita F, Naitoh T. The background adaptation of the flatfish, Paralichthys olivaceus. Physiol Behav. 1991;50:185-8.

Han D, Xie S, Lei W, Zhu X, Yang Y. Effect of light intensity on growth, survival and skin color of juvenile Chinese longsnout catfish (Leiocassis longirostris Günther). Aquaculture. 2005;248:299-306.

Hanlon R. Cephalopod dynamic camouflage. Curr Biol. 2007;17:400-4

Hur SW, Lee CH, Lee SH, Kim BH, Kim HB, Baek HJ, Lee YD. Characterization of cholecystokinin-producing cells and mucus-secreting goblet cells in the blacktip grouper, Epinephelus fasciatus. Tissue Cell. 2013;45:153-7.

Ju SH, Cho GB, Sohn JW. Understanding melanocortin-4 receptor control of neuronal circuits: toward novel therapeutics for obesity syndrome. Pharmacol Res. 2018;129:10-9.

Kalinowski CT, Robaina LE, Fernandez-Palacios H, Schuchardt D, Izquierdo MS. Effect of different carotenoid sources and their dietary levels on red porgy (Pagrus pagrus) growth and skin colour. Aquaculture. 2005;244:223-31.

Kasagi S, Mizusawa K, Takahashi A. The effects of chromatic lights on body color and gene expressions of melanin-concentrating hormone and proopiomelanocortin in goldfish (Carassius auratus). Gen Comp Endocr. 2020;285:113266.

Kim SH, Lee CH, Song YB, Hur SW, Kim HB, Lee YD. Ultrastructure of late spermatids and spermatozoa during spermiogenesis in longtooth grouper Epinephelus bruneus from Jeju, Korea. Tissue Cell. 2013;45:261-8.

Kittilsen S, Schjolden J, Beitnes-Johansen I, Shaw JC, Pottinger TG, Sørensen C, Braastad BO, Bakken $M$, Øverli $\varnothing$. Melanin-based skin spots reflect stress responsiveness in salmonid fish. Horm Behav. 2009;56:292-8.

Klein M. 2018. Get average color of image. Retrieved from https://matkl.github.io/ average-color/ on Jun 20.

Kobayashi T, Urabe K, Winder A, Jiménez-Cervantes C, Imokawa G, Brewington T, Solano F, García-Borrón JC, Hearing VJ. Tyrosinase related protein 1 (TRP1) functions as a DHICA oxidase in melanin biosynthesis. Embo J. 1994;13:5818-25.

Kohno H, Diani S, Supriatna A. Morphological development of larval and juvenile grouper, Epinephelus fuscoguttatus. Jpn J Ichthyol. 1993;40:307-16.

Kondo T, Hearing VJ. Update on the regulation of mammalian melanocyte function and skin pigmentation. Expert Rev Dermatol. 2011;6:97-108.

Korner A, Pawelek J. Mammalian tyrosinase catalyzes three reactions in the biosynthesis of melanin. Science. 1982;217:1163-5.

Lee CH, Hur SW, Kim BH, Soyano K, Lee YD. Induced maturation and fertilized egg production of the red-spotted grouper, Epinephelus akaara, using adaptive physiology of photoperiod and water temperature. Aquac Res. 2020;00:1-7.

Lee $\mathrm{CH}$, Hur SW, Na OS, Baek HJ, Noh CH, Han SH, Lee YD. Induction of primary male in juvenile red spotted grouper Epinephelus akaara by immersion of 17a-methyltestosterone. Dev Reprod. 2014;18:127.

Lee JS, Britt LL, Cook MA, Wade TH, Berejikian BA, Goetz FW. Effect of light intensity and feed density on feeding behaviour, growth and survival of larval sablefish Anoplopoma fimbria. Aquac Res. 2017;48:4438-48.

Liu Y, Mou Z, Xu G, Li Y, Wang C. The effect of light intensity on the growth of Brachymystax lenok (Pallas, 1773). Aquac Res. 2012;43:1838-44.

Luchiari AC, De Morais-Freire FA, Koskela J, Pirhonen J. Light intensity preference of juvenile pikeperch Sander lucioperca (L.). Aquac Res. 2006;37:1572-7.
Matsuda K. Recent advances in the regulation of feeding behavior by neuropeptides in fish. Ann Ny Acad Sci. 2009;1163:241-50.

Mizusawa K, Yamamura Y, Kasagi S, Cerdá-Reverter JM, Takahashi A. Expression of genes for melanotropic peptides and their receptors for morphological color change in goldfish Carassius auratus. Gen Comp Endocr. 2018;264:138-50.

Odiorne JM. Color changes. In: Brown ME, editor. The physiology of fishes, vol. 2. New York: Academic press; 1957. p. 387-401.

Paripatananont T, Tangtrongpairoj J, Sailasuta A, Chansue N. Effect of astaxanthin on the pigmentation of goldfish Carassius auratus. J World Aquacult Soc. 1999:30:454-60.

Park JM, Lee SH, Yun SM, Na HC, Han KH. Egg development and morphology of larvae and juveniles of spotted knifejaw, Oplegnathus punctatus. Korean J Ichthyol. 2015;27:71-7.

Pavlidis M, Karkana M, Fanouraki E, Papandroulakis N. Environmental control of skin colour in the red porgy, Pagrus pagrus. Aquac Res. 2008:39:837-49.

Petrell RJ, Ang KP. Effects of pellet contrast and light intensity on salmonid feeding behaviours. Aquacult Eng. 2001;25:175-86.

Reichard M, Jurajda P, Ondračková M. The effect of light intensity on the drift of young-of-the-year cyprinid fishes. J Fish Biol. 2002;61:1063-6.

Richmond HE, Hrabik TR, Mensinger AF. Light intensity, prey detection and foraging mechanisms of age 0 year yellow perch. J Fish Biol. 2004;65:195-205.

Rimmer MA, Glamuzina B. A review of grouper (Family Serranidae : Subfamily Epinephelinae) aquaculture from a sustainability science perspective. Rev Aquacult. 2019;11:58-87.

Seiji M, Shimao K, Birbeck MSC, Fitzpatrick TB. Subcellular localization of melanin biosynthesis. Ann Ny Acad Sci. 1963;100:497-533.

Sköld HN, Aspengren S, Wallin M. Rapid color change in fish and amphibiansfunction, regulation, and emerging applications. Pigm Cell Melanoma R. 2013;26:29-38

Song YB, Oh SR, Seo JP, Ji BG, Lim BS, Lee YD, Kim HB. Larval development and rearing of longtooth grouper Epinephelus bruneus in Jeju Island, Korea. J World Aquacult Soc. 2005;36:209-16.

Sulaimon SS, Kitchell BE. The biology of melanocytes. Vet Dermatol. 2003;14:57-65.

Suzuki H. Evolutionary and phylogeographic views on Mc1r and Asip variation in mammals. Genes Genet Syst. 2013:88:155-64.

Suzuki I, Im S, Tada A, Barsh G, Hearing V, Scott C, Akcali C, Davis MB, AbdelMalek Z. Participation of the melanocortin-1 receptor in the UV control of pigmentation. In: J Invest Derm Sym P. 1994;4:29-34.

Takahashi A, Tsuchiya K, Yamanome T, Amano M, Yasuda A, Yamamori K, Kawauchi $\mathrm{H}$. Possible involvement of melanin-concentrating hormone in food intake in a teleost fish, barfin flounder. Peptides. 2004;25:1613-22.

Wang YJ, Chien YH, Pan CH. Effects of dietary supplementation of carotenoids on survival, growth, pigmentation, and antioxidant capacity of characins, Hyphessobrycon callistus. Aquaculture. 2006;261:641-8.

Yamanome T, Amano M, Takahashi A. White background reduces the occurrence of staining, activates melanin-concentrating hormone and promotes somatic growth in barfin flounder. Aquaculture. 2005;244:323-9.

Yamashita YT, Aritaki M, Kurita Y, Tanaka M. Early growth and development of reciprocal hybrids of the starry flounder Platichthys stellatus and stone flounder Kareius bicoloratus. J Fish Biol. 2014;84:1503-18.

Yasir I, Qin JG. Effect of light intensity on color performance of false clownfish, Amphiprion ocellaris Cuvier. J World Aquacult Soc. 2009;40:337-50.

\section{Publisher's Note}

Springer Nature remains neutral with regard to jurisdictional claims in published maps and institutional affiliations.

Ready to submit your research? Choose BMC and benefit from:

- fast, convenient online submission

- thorough peer review by experienced researchers in your field

- rapid publication on acceptance

- support for research data, including large and complex data types

- gold Open Access which fosters wider collaboration and increased citations

- maximum visibility for your research: over $100 \mathrm{M}$ website views per year

At $\mathrm{BMC}$, research is always in progress.

Learn more biomedcentral.com/submissions 